\title{
Use of Information and Communications Technologies by Indigenous Civil Society Organizations in Ecuador
}

Lupien, P. and G. Chiriboga. 2019. Use of Information and Communications Technologies (ICTs) by Indigenous Civil Society Organizations, Information, Communication and Society, 22(8): 1029-1043.

Pascal Lupien (corresponding author) Assistant Professor Assistant Professor, Brock University 1812 Sir Isaac Brock Way St. Catharines, ON L2S 3A1 (Canadá)

E-mail: plupien@brocku.ca orcid.org/0000-0002-6698-9910

\section{Gabriel Chiriboga}

Gestión y Desarrollo Social, Universidad Técnica del Norte, Ibarra, Ecuador chiribogagabo@gmail.com

Pascal Lupien holds a PhD in Political Science. He teaches in the Latin American and Caribbean Studies program, College of Arts at the University of Guelph and is a Research Fellow at the Balsillie School of International Affairs.

Gabriel Chiriboga holds the title of Engineer in Social Planning and Development from the Universidad Técnica del Norte (UTN) in Ibarra, Ecuador. He works as a researcher at the UTN. 


\section{Use of Information and Communications Technologies (ICTs) by Indigenous Civil Society Organizations}

Indigenous peoples are among the most marginalized population groups in the Western Hemisphere. In Latin America, they have engaged in diverse forms of collective action with varying degrees of success. Previous research has studied the "traditional" social movement strategies used by some of the more successful groups. We know relatively little, however, about how Indigenous groups use information and communication technologies (ICTs) to pursue their goals and engage in civic participation. While a growing number of researchers are studying the use of ICTs for the purpose of mobilization, recent studies on the use of technology by social movements tend to focus on a handful of high-profile Western cases of large-scale mobilization. Transnational NGOs have worked with Indigenous organizations to transfer technology and help set up webpages, social media accounts and hardware but we still know little about how they are being used and in what direction these technologies affect the power relationship in this very distinct social and political context. This study fills some of the gaps in our knowledge by looking at how Ecuadorian Indigenous organizations are using ICTs, the barriers they face and the factors that enhance or diminish their capacity to use technology effectively. It finds that while there are benefits and disadvantages, the barriers these groups face with respect to ICTs may be tipping the balance of power away from Indigenous movements.

Keywords: ICTs, social movements, collective action, Internet and political organization, communication and identity, power, Indigenous peoples, Latin America

Indigenous peoples remain among the most marginalized population groups in the Western Hemisphere. The wave of democratization that swept Latin America in the 1980s and 1990s provided new political opportunities and groups representing Indigenous communities have engaged in diverse forms of collective action with varying degrees of success. This has resulted in a wealth of literature addressing the emergence and development of Indigenous social movements in the Americas. The research has focused on mobilization, usually selecting visible and successful cases that involve traditional disruptive tactics. At the same time, a growing number of researchers are studying the use of information and communication technologies (ICTs) for the purpose of mobilization and civic activism. Some authors present technology as potentially empowering while others argue that advantages enjoyed by groups in the "real" world will be reproduced in cyberspace. Yet these two streams of the literature do not intersect and 
surprisingly little attention has been paid to the impact of new technologies on the capacity of Indigenous civil society to advance collective goals.

ICTs have become increasingly accessible to poor and remote communities throughout much of Latin America. Transnational NGOs have worked extensively with Indigenous organizations in particular to transfer technology and help set up webpages, social media accounts and hardware but we know little about the consequences of these efforts. This article begins to address these questions by examining the use of ICTs by Indigenous civil society organizations (CSOs) in Ecuador, a country that has produced one of the world's strongest Indigenous movements. We ask about the impact of ICTs on the capacity of Indigenous groups to represent and pursue the interests of their constituents and the ways in which ICTs strengthen or hinder their capacity to do so.

Responding to these questions not only provides valuable empirical evidence but contributes to a developing area of theory as scholars attempt to reconceptualize political action in the age of the Internet. The theory that is emerging has not adequately considered the unique circumstances of Indigenous peoples, who are not only excluded in socioeconomic terms but have a distinct set of demands and claims that revolve around territory, identity and autonomy.

\section{Indigenous Social Movements and ICTs}

There is a wealth of literature addressing the emergence and development of Indigenous social movements in the Americas. Authors consider the role of factors such as pre-existing structure, political opportunities, identity and transnational networks in facilitating Indigenous mobilization. This research has shed light on why organizations representing marginalized Indigenous groups have emerged and how they have used "traditional" disruptive social movement tactics, such as marches, roadblocks and alliance building (Van Cott, 1994; Brysk, 
2000; Albó, 2004; Postero and Zamosc, 2004; Yashar, 2005; Postero, 2007; Lucero, 2008; Rice, 2012).

The relative decline of the Indigenous protest cycle by the mid-2000s meant that research on collective action turned elsewhere (Mijeski and Beck 2011). This period coincides with the emergence of social media and a dramatic upswing in the use of ICTs in Western countries and among middle-class groups in the Global South. We know little about how Indigenous groups have innovated and adapted new technologies that have emerged over the past decade. Yet a growing number of researchers are studying the use of information and communication technologies (ICTs) for the purpose of civic participation and mobilization. In his influential work, Castells $(2009,2009 \mathrm{~b})$ argues that power now centers on networks organized around new media and communication technologies. Some see a shift in the very nature of civil engagement, with ICTs allowing for a permanent state of organizing that does not transfer power to organizations but results in non-directed campaigns (Bennett \& Segerberg, 2012; Anduiza, Cristancho \& Sabudcedo, 2014). These movements are diffuse and unstructured, but have succeeded in bringing together potentially powerful coalitions with limited identity and ideological ties (Bennett, 2003; Biekart \& Fowler, 2013; Langman, 2005). Participation is far more individualized, with collective identity and ideology taking a back seat to personalized action frames (Bennett \& Segerberg, 2011). This "networked individualism" is replacing collective social narratives and hierarchical organizations (Bennett, 2003).

Some authors present technology as potentially empowering, particularly for groups with limited resources. They argue that communications technologies reduce the cost of participation and shift the balance of power toward resource-poor players who do not have large, wellfinanced organizations at their disposal (Bennett, 2003; Bimber, Stohl \& Flanagin, 2005; 
Boulianne, 2009). ICTs (social media in particular) have led to an increase in activism against the neoliberal order and provided opportunities for activists to challenge existing power structures and to bypass traditional media, which often distort social movement's messages (Carty, 2002; Pickerill, 2003; Carty \& Onyett, 2006; Boulianne, 2009; Stein, 2009; Biekart \& Fowler, 2013). Some argue that technology is thus re-shaping the repertoire of strategies that activists can draw on. Internet-based technologies can be used to circulate information beyond the control of states and other powerful actors, to mobilize through the dissemination of emotional audio and video campaigns and to coordinate and organize protest activities that blend different strategies and tactics rather than reproducing the structures of formal organizations in cyberspace (Chadwick, 2007; Castells, 2012). ICTs may also facilitate the mobilization of actors who have not been involved in political participation in the past by reducing participatory inequalities (Anduiza, Cristancho \& Sabudcedo, 2014). This perspective assumes that these individuals have access to technologies and adequate infrastructure.

Others have been more critical of the impact of ICTs on social movements. Norris (2001) questioned whether they may deepen the divide between those with the resources to use ICTs effectively and those who do not. Pointing out that basic access is required before marginalized actors can take advantage of the potential benefits of digital technologies, she suggests that they may in fact serve to reinforce the gap between rich and poor. More recently Norris and Inglehart (2013) find persistent disparities continue to exist, from access to hardware to the speed of Internet connections. In the Latin American context, while overall access to the Internet has improved considerably over the past decade (particularly among middle and higher-income youth), there is a significant gap between socioeconomic groups, with only $2 \%$ of the poorest households having access (Trucco, 2013). A divide may exist between organizations as well, as 
some may lack the resources and capacity to use technology effectively (Stein 2009). Even those who see value in the use of ICTs by social movements warn that they cannot necessarily replace more traditional forms of activism and organization (Pickerill, 2003; Van Aelst \& Walgrave, 2003; Langman, 2005).

Most of the studies on the use of ICTs by social movements focus on Western democracies (Breuer \& Groshek, 2014). The world's Indigenous peoples (who are often among the poorest socioeconomic group in their respective countries) are largely absent from the discussion. A notable exception is the use of the Internet by Mexico's Zapatista Army of National Liberation (EZLN) in the early 1990s. The Zapatistas' supporters created a transnational network allowing activists to use the Internet to engage in protest and put pressure on the Mexican government at home and abroad. Much of this was accomplished through the creation of a plethora websites focusing on various social and economic issues promoted by the Zapatistas (Cleaver, 1998; Garrido \& Halavais, 2003). This has been credited with creating a shift in how social movements operate (Chadwick, 2007; Castells, 2009b). It is important to note, however, that the Zapatista networks relied heavily on websites created by foreign NGOs in support of Indigenous causes, and there is little understanding of how Indigenous movements can create and use ICTs independently without support of these transnational actors. The events also predate the existence of social media.

\section{Indigenous Mobilization in Ecuador}

Indigenous groups in Ecuador began mobilizing as early as the 1920s through organizations linked to the traditional left. The first independent movements emerged in the Amazonregion in the 1960s and 1970s. These include various provincial-level organizations and 
a regional body, the Confederation of Indigenous Nationalities of Ecuadorian Amazon (CONFENIAE). Born out of the struggles for agrarian reform in the Andes, the Ecuador Runakunapak Rikcharimuy (ECUARUNARI) was founded in 1972 to represent the peoples of the far more populous Andean highlands and to promote Indigenous identity (Yashar, 1998). CONFENIAE and ECUARUNARI later helped to found the first national Indigenous organization in Latin America, the Confederation of Indigenous Nationalities of Ecuador (CONAIE). Under the leadership of CONAIE, Indigenous groups in Ecuador employed a wide and evolving repertoire of tactics to pursue their demands and achieved significant policy outcomes that demonstrated the power of what many have called Latin America's strongest Indigenous movement (Yashar, 2005). The 1990 National Indigenous Uprising brought together activists fighting for land-related grievances in both the Andes and the Amazon and effectively changed the perception of Indigenous peoples in Ecuador (Selverston-Scher, 2001). Their newfound visibility allowed these actors to draw other stakeholders to their cause and by the mid-1990s churches, NGOs and other sectors such as labour unions were openly supporting Indigenous causes. The number of local and regional Indigenous organizations exploded during this period, raging from politically-oriented groups to agricultural cooperatives. Unlike many recent social movements, their demands have consistently revolved around collective goals, community and place (Lupien, 2011; Van Cott 2008).

Observers of Ecuadorian politics have noted that citizens are increasingly turning to social media to challenge the government and exchange ideas (Judem, 2012). According to the International Telecommunications Union, however, only 35 percent of Ecuadoreans used the Internet in 2013. Indigenous communities in particular tend to be poorer and more remote, which suggests that their communities are likely to be excluded from this new online activism. If social 
media is replacing traditional tactics such as marches and roadblocks and if Indigenous communities' access to ICTs is limited, what does this mean for their capacity to pursue their interests?

\section{Methodology}

The fieldwork was carried out from July to December 2016. Ecuador was chosen due to the strength and diversity of its Indigenous organizations. The researchers conducted semistructured interviews with fifteen leaders from eight organizations in three Ecuadorian provinces with high Indigenous populations and a history of social activism and strong organizations (Imbabura, Pichincha and Chimborazo). The eight cases were chosen to represent the variety of Indigenous CSOs in the country: one large national organization, one provincial level CSO, three unions or confederations representing multiple communities in a given region, one organization representing local rural Indigenous governments and two smaller, locally-oriented organizations. In terms of representation, the organizations range in size from hundreds of thousands (the national association) to 80 members (for one of the smaller local cooperatives). The regional associations represent from 10 to 34 organizations and 6,000-30,000 people. Comparing different organizations helped the researchers to understand the different benefits and/or disadvantages of using ICTs and to expose the contextual factors that enhance or diminish the capacity of our cases (Indigenous organizations) to use ICTs effectively. The researchers interviewed both the directors of these organizations and those who are best placed to know about how the organizations use technology (these are sometimes, but not always the same individuals). All interviews were conducted in Spanish. 
The online presence of these organizations was also analyzed in order to understand how social media and websites are being used. Given the modest amount of information available, data was manually extracted from the organizations' websites, blogs and social media accounts, and saved to a spreadsheet. This data was subsequently uploaded into NVivo in order to analyze the content of these sites. This allowed the researchers to identify common themes and develop a series of categories based on how Indigenous organizations are using the online tools available to them.

\section{Findings}

\section{Current Uses of ICTs}

The overall picture is that the use of ICTs by Indigenous CSOs is still very limited and the impact on their daily activities, mobilization efforts and long-term civic participation is minimal. Directors and activists clearly see the value of technology and all of those we spoke to support using ICTs to make their work easier and more efficient. They feel that it is impossible for citizens or the organizations that represent them to be completely integrated into society without using technology. Almost all express interest in innovation and appreciate people or projects that can bring innovative solutions in support of the communities. But this does not mean pursuing technology for technology's sake; directors are looking for ICTs that can make their lives easier and help them to better serve their communities.

The most commonly used technologies include cellphones, computers, e-mail, websites and social media platforms such as Facebook. Cellphones are relatively common and are used by both CSOs as well as by people in the communities they serve. There is some variation between the organizations; some confirmed that all or most of their members have cellphones, while 
others said that many of their constituents do not. In all cases, smartphones remain relatively rare and cellphones are used primarily for voice or text communication. Given the cost of more expensive models as well as data plans, this means that few are able to access the Internet using mobile technology. All but one of the organizations we studied have computers in their head office and use Internet and e-mail. Computers were acquired through funding proposals, or were donated by domestic or international NGOs. Most offices have three to four computers for employees and two of the larger organizations have additional machines for members to use on a drop-in basis. For the most part, these are older desktop models, with most having been donated second hand. However, while the majority of organizations have some access to these technologies in their headquarters, most directors lament that their members, particularly people in rural communities, do not have access. They feel that this limits the organizations' capacity to use them effectively.

Seven of the eight organizations we studied have a website, but a review of the content reveals that they are limited in nature and generally not used to their full potential. Six of the seven provide only basic content (history, vision and goals of the organization and information about community projects) and are very static, having not been updated for years. Only one organization has a fully and regularly updated website. They use it to post annual reports about organization's activities, budget and financial documents (for the sake of ensuring transparency), information about workshops, news (cultural, sports, local events), information about current development projects and educational videos. Websites are primarily in Spanish, although some have translated certain pages into English with the intention of ensuring that their vision and goals are accessible to a wider audience. There is very little content available in Indigenous languages such as Kichwa. 
Indigenous CSOs have done more with social media than with their websites. Six of the eight organizations have active Facebook accounts, although some use them more frequently than others. The Facebook pages of Indigenous organizations have a moderate number of followers: from 500 for smaller organizations to over 1,500 for the larger ones. The pages are mainly used to share information about events such as parades and festivals, pictures of these events, community meetings and coverage of the organization's activities (showing the results of projects and their beneficiaries). The organization with the most developed Facebook content includes stories about sustainable tourism, information about agricultural products from the community, training and educational opportunities, educational videos on topics such as the origin of quinoa, invitations to communal assemblies, sharing local government documents, political satire (often critical of right-wing parties), and information about opportunities for young people such as training or bursaries. This organization's leader stated that they always post everything that affiliated Indigenous movements do on Facebook, so that people (including outside of the communities) know about the hard work of the Indigenous movements. A review of the Facebook pages reveals a modest level of interaction. A relatively small number of followers leave comments and suggestions; others show their support or opposition for something the organization is doing. One leader said that this feedback could be helpful in determining future directions.

Only one of the organizations uses Twitter. This account has 76 followers, but only 20 tweets (from 2011-2013). The tweets focused on events and celebrations, links to news items (newspapers and TV shows) which feature the organization or interviews with leaders, news about agricultural products, some political statements and, retweets from sites. 
Two of the organizations we studied had created and posted videos on sharing sites such as YouTube and Vimeo. The content includes interviews about the organization's goals and political activities, talking about and showing scenes from their communities, taking about their traditions and discussing projects such as "development with identity". Two of the organizations host local radio shows, with content in Kichwa, to discuss issues relevant to the communities. One organization has completed an agreement with a local television station to diffuse a regular information series about programs and projects.

Communication is essential for any CSO and is the most commonly identified benefit of using ICTs. E-mail is used by all of the organizations we studied for sending documents and to communicate with other CSOs, funders and government agencies, although generally not with their own communities due to lack of access among members. Leaders noted that ICTs can help to strengthen ties between organizations or government agencies (particularly local government) in that they allow for faster and more efficient communication and help activists work in a more articulated way. They also allow organizations to have a better understanding and appreciation for what is happening in other communities, which helps to coordinate efforts. As one leader said: "They help to bring us closer together, to make the (regional) territory smaller because we have a lot of isolated communities and before we often didn't know what was happening elsewhere. But using TICs we can communicate, we can know about activities happening in other parishes." ${ }^{\prime 1}$ While this type of communication has been enhanced between larger and midsized organization leaders, interaction between communities, or between CSOs representatives and leaders of rural villages remains limited. Technology is rarely used here; many of the community leaders do not have access to the Internet and still depend on telephones or print documents that are delivered in person. 
While many in the communities they represent do not have Internet access, Indigenous leaders see the value of having an online presence beyond their communities. The director of an organization with a fairly active Facebook presence claimed that he posts information about events and pictures as soon as possible because it is important for the public to know what they are doing. Another leader captured what many of his colleagues expressed:

"Things like Facebook pages can be used to provide more visibility and perhaps this can be important in terms of getting messages out there. Government agencies, as well as potential allies do tend to have a presence online, so it is important to be there too. Plus, we need the make sure the general public knows what are movements are doing from our own perspective; otherwise, we allow others to tell our story."

Information gathering is another core activity of Indigenous CSOs and activists claimed that ICTs have made their jobs easier on this front. As one leader said, technology "brings us closer to what is going on. We are better informed, and we can get information directly without having a third party select and interpret it for us." ${ }^{, 3}$ The Internet is primarily used for access to information about relevant legislation, data and statistics, social trends or current news that may impact the community or the organization's goals. It is seen as a particularly valuable tool for information gathering because it provides access to sources that would otherwise be unavailable to activists. In the past, it was necessary for CSO representatives to travel to the cities or rely on external allies to deliver information to them.

Many Indigenous organizations or their members produce various types of goods, such as agricultural products, clothing, leather goods, art and crafts. Some have started to use the Internet to help them make decisions about what potential consumers are looking for. For example, a women's cooperative that produces and sells tradition Indigenous clothing has a dedicated member that browses websites to find out about current styles and seasonal trends. They claim 
that seeing what others are offering gives them new ideas and helps with thinking about marketing their products. They use the page to advertise and sell their products.

Most also stressed, however, that technology is a means to an end; they feel that it can only be helpful if Indigenous aspirations are taken seriously. As one director said: "Technology helps us, but some things remain constant: we need people to take us seriously and accept out proposals. If our proposals aren’t accepted, technology or no technology, we're no further ahead." Others also pointed out that ICTs cannot replace "old fashioned" forms of communication, noting the importance of community to Indigenous culture.

"It is always better to communicate directly, face to face, with the people. Technology can also be a good means, but it depends on how it is used. And there are limits to the quality of communication on the Internet, it loses the human touch. Its fine to use it, but sometimes human contact is needed." $" 5$

CSO directors and activists unanimously felt that the Internet is not being used its full potential for communication. Directors and activists are interested in using technologies to work with similar organizations on matters of mutual interest, to see what other organizations are doing, to share ideas and experiences, to discuss projects and initiatives and to reflect on successes and failures. Most also mentioned the potential of ICTs to enhance communication with Indigenous organizations in other parts of Ecuador (such as the remote Amazon region) and in other countries. Particularly with the smaller CSOs, there is practically no communication with Indigenous organizations beyond the region but all of the representatives recognize the value in developing ties and believe that technology can make this possible. Directors would also like to use ICTs to facilitate communication between organizations and their communities, including calling community meetings, sharing what happened at these meetings, engaging in participatory decision-making, promoting events and soliciting feedback from constituents. 
Organizations also understand the potential of the Internet and social media in adverting and selling their products. Some felt that technologies could help them to export their products internationally to consumers in Western countries who are interested in purchasing Indigenous handicrafts and clothing online. They would also like to have software, backed up by training, to organize and administer their budgets, sales and related transactions.

\section{Barriers to using ICTs}

There was a great deal of consistency with respect to barriers that prevent Indigenous CSOs from using ICTs to their full potential. The challenges most frequently identified by directors and activists can be divided into those related to human capacity and those caused by limited infrastructure.

The lack of training, knowledge and expertise with respect to ICTs was the most commonly identified problem; all of the organizations' representatives identified this the primary obstacle to using technology. The majority of Indigenous activists and community members do not have the skills required to use ICTs effectively and the organizations do not have resources to train citizens or to hire technical experts. As one director put it:

"Technology has to be learned and we don't have the capacity to extend this to our communities. So we use old fashioned means of communication, including simply walking to communicate in person. I think this means we are losing out, we are falling behind other groups that are using ICTs effectively." 6

As noted earlier, the organizations we studied tended to have simple, static websites that have not been updated in years. Directors attributed this to fact that they do not have anyone with the skills to update their sites. The websites were created in the 1990s or 2000s by well-meaning individuals from outside the community (often supportive Western social movement activists or 
academics) but these partners have since moved on and were not able to provide the training necessary to maintain the sites.

It is also worth noting that there is a gender and age gap with respect to skills acquisition. Female activists noted that fewer women than men know how to use ICTs or have social media accounts, especially older women. When we consider how these technologies are being used (for access to information, entrepreneurial activities, and so forth) this gender gap may have significant consequences on the ability of women and the CSOs that represent them to pursue their collective and individual goals. According to community leaders, the capacity to use ICTs also diminishes considerably for people over 30 .

Given the importance that these organizations place on communication, a closely related issue is the lack of people with related professional expertise. Many COS directors pointed out that using ICTs effectively requires not only technical know-how, but also marketing and promotional skills, the ability to write compelling press releases, and proficiency in creating captivating multimedia content to post on social media. This was identified as a socioeconomic issue; many of those who work for the Indigenous organizations are volunteers and people who have developed these professional skills expect a decent salary. The cost of postsecondary education is high in Ecuador and finding someone with the required expertise in ICTs or communications who is willing to work on a volunteer basis is nearly impossible. Within the communities, those who do have the necessary skills tend to be very busy with their own work and lack the time or the will to help Indigenous organizations. Many who receive a formal education leave the communities to get jobs in the cities.

Lack of adequate infrastructure in Indigenous communities is the second most commonly identified barrier to using ICTs. While most of the organizations we studied have at least basic 
equipment and Internet access in their offices, many communities, particularly isolated rural areas, cannot afford to bring technology to their people. With government support, some administrative districts have been setting up telecentros (community centres where people can access computers and the Internet) but these are usually installed in the main town of each district. People from the rural communities do not have easy access and must frequently travel long distances on foot to access them. Organizations point out that the most isolated communities could benefit most from better access to ICTs, especially with respect to communication.

Many organizations rely on government funding to survive, which limits how they can use ICTs to engage in the political process. Directors and activists noted that they must use caution about what they post on social media, because it may not be in the best interests of the organization. This puts CSOs at a disadvantage vis à vis both government departments and privately funded groups that do not depend on public funding. As one activist stated:

"There are a lot of virtual wars between political parties or between parties and business groups or middle class groups. But we are careful about taking positions because it can hurt us and our responsibility is to respond to the needs of people we represent. We depend so much on the state, on funds from government agencies, we can't offend them by taking strong positions."

While all CSO leaders acknowledged these barriers, there were different perspectives with respect to whether the growth of ICTs provide benefits or threats to Indigenous peoples. For some, the fact that they make the work of CSOs easier is a significant benefit, even if the technologies do not reach most people in the communities.

"They strengthen our ability to engage in the political process because it used to be so difficult to do things, such as pay bills across all of the parishes, now we have software that can streamline and manage all of that. We can also do a lot more promotion and have access to a lot more information, with the goal being making life better for our communities." 
For others, Indigenous communities and the organizations that represent them are actually at a disadvantage when compared with the past. Much of this stems from a digital divide that Indigenous leaders are keenly aware of. They understand that government and other forces do not face the same barriers, that they do have access to skills and infrastructure required to use ICTs for their purposes. One director stated that: "For them (ICTs) to be useful, we have to know how to use them as well as other groups in society. On social media, when it comes to political themes, government dominates. ${ }^{\prime 8}$ Some activists also pointed out that governments or other powerful actors, who do not face the barriers that Indigenous communities must confront, can use ICTs more effectively to suppress the efforts of Indigenous organizations or to undermine political efforts:

"there is more and more bombarding people with political themes and it is getting stronger. They (state actors) are publishing their ideas, activities and projects. It is good that they are informing people, but it is like being in campaign mode all the time. Politicians have much better understanding and manage TICs much more thoroughly than the average person in their community. People are more vulnerable to being sucked in to messages they put out."

Many respondents also noted that most of their members are not on social media, so these tools are not particularly useful for mobilizing those who would support Indigenous social movements. The director of a CSO that had been involved in numerous protest activities in the 1990s expressed the sentiments of many of our respondents:

"Some groups, middle-class people and young people in the cities use social media to mobilize supporters of particular causes. We see this in our cities and in other countries all over the world. They say that using Facebook and Twitter helps people to mobilize, makes it easier for social movements to mobilize their supporters. Well maybe it makes it easier for the middle-classes, but certainly not for us. No. How can we use these technologies to mobilize when most of our members don't yet have access or don't know how to use them?"10

Others pointed to the loss of close contact and identity as a threat:

"The strength in our movements has always come from close bonds and from a sense of Indigenous identity. If everything goes online, we lose this, this leads to more individualism and that takes away from our greatest advantage when it comes to mobilizing our people." 11 
Many activists, and some of the directors, recognized that this imbalance can be reproduced within Indigenous communities. We have seen that leaders and CSO directors are more likely than their constituents to have access to equipment and that Internet access is limited to larger towns (where the CSO's headquarters are located) but provide sparse coverage in rural areas. This creates a centralization of ICTs in the hands of Indigenous leaders, allowing these individuals the ability to manage and disseminate information according to their interests and preferences. Many of the directors acknowledged that regardless of their intentions, this can lead to partial or politicized information to support their own agendas and counters one of the most significant potential benefits of ICTs.

\section{Discussion}

Protest, activism and interest representation in the $21^{\text {st }}$ century are increasingly characterized by the use of ICTs. Social scientists studying this phenomenon need to develop a better understanding of the extent to which technologies shift the balance of power between marginalized sectors (and the organizations that represent them) and the state or other powerful actors. The research presented in this article paints a mixed picture when it comes to organizations representing Indigenous peoples. On the one hand, ICTs supply resource-poor actors with information and tools to pursue their goals more efficiently. On the other hand, ICTs may put organizations representing marginalized peoples at a disadvantage because their communities lack access, infrastructure and training, which provides more powerful groupssuch as state actors - with an advantage. At this point in time, it appears that the disadvantages outweigh the benefits. Indigenous organizations face barriers to using technologies that the literature on the use of ICTs by social movements does not adequately address. There are a 
number of potential solutions, however, that Indigenous organizations and their allies can pursue in order to correct some of the inequalities that have long excluded their voices from the public sphere.

Enhanced communication is a benefit in itself for marginalized communities. The literature has demonstrated the role of ICTs in facilitating communication and coordination between organizations with similar goals. Communication with government agencies and NGOs (including supportive funders abroad) is another obvious advantage. Having a social media presence can allow Indigenous actors to tell their stories without an intermediary, promote their activities and join conversations beyond their communities. While this may be more likely to reach those already inclined to support their agenda, it can serve as a tool for brining attention to their causes and solidifying support among activists and citizens at home and abroad. In the $21^{\text {st }}$ century, CSOs need to have an online presence or risk having their voices left out of important conversations. With some training and support, maintaining this presence is possible even where access is limited in the wider communities. ICTs can also strengthen organizations' ability to engage in day to day administrative tasks, leaving more time for busy directors to devote to more important activities. The ability to sell revenue-generating products to international consumers beyond local crafts markets has the potential to strengthen the finances of some CSOs.

While communication may be facilitated in some respects, the state and other powerful actors are able to better take advantage of ICTs (due to access to equipment, training and expertise) to disseminate their messages. Even when Indigenous organizations have access to ICTs, people in their communities may not. If the Internet has become the primary source for information, this puts the "resource poorest" at a disadvantage with respect to other actors. This digital divide may reproduce and even exacerbate the socioeconomic inequalities that already 
exist between Indigenous and non-Indigenous communities. This gap is particularly troubling with respect to Indigenous youth. The lack of access and training opportunities in their communities widens the already significant gap between them and middle-class urban youth. This has implications for education and future employment prospects, threatening to maintain long-established patterns of underdevelopment in Indigenous communities. We have also seen that women were less likely than men to use ICTs. Even within organizations representing excluded sectors, information tends to be concentrated at the top and leaders have their own preferences and agendas.

Much of the literature on the intersection of ICTs and social activism is based on Western case studies or on middle-class urban movements in developing countries. It overlooks many of the particular challenges faced by primarily rural Indigenous communities, as well as their unique circumstances and perspectives. While considering these challenges is essential for those seeking to understand the implications of technology on the ability of marginalized groups to engage in the public sphere, we must also reflect on solutions that can allow these actors to benefit from using ICTs.

While full access and universal training are unlikely in the context of a developing rural society, Indigenous organizations understand the potential benefits of using ICTs to support communication, sharing of experiences, political engagement, training and commercialization of their products. Their task is to leverage these benefits to extent possible given their limited resources. Indigenous social movements do have a history of finding innovative ways to use technologies. In the $20^{\text {th }}$ century, organizations used video and radio to share messages, mobilize supporters and promote culture and Indigenous languages within and beyond communities (Lupien 2017). Observers have characterized video as a tool for empowerment which allows 
Indigenous content producers to draw on ancestral forms of communication such as storytelling in order to insert their cultural narratives into the broader public sphere (Salazar 2007).

The current training and infrastructure challenges are perhaps greater given the variety and complexity of ICTs available today. Organizations could meet some of their self-identified goals by taking advantage of technologies already available to them. Given that most organizations have Internet access in their offices, social media sites such as Facebook and free applications such as Skype could be used to communicate between organizations at home and abroad, share experience and coordinate action. Currently used social media platforms could also improve communication with relevant government departments and with the greater public so that Ecuadorians can hear directly from Indigenous movements instead of hearing messages that have been filtered or interpreted by the media. Organizations can also access technology that could allow for more effective commercialization of their products both at home and abroad. Some of the cooperatives, for example, could create online stores using basic social media platforms and use sites such as PayPal to collect and accept payments.

Expanding infrastructure to local residents poses a greater long-term challenge. Having wifi in central plazas in smaller communities would be helpful but most local governments do not have sufficient resources and these investments are unlikely to come from the private sector as companies do not see a profit in expanding access to rural Indigenous communities. Options could include "minimal computing" (computing under significant equipment, software, education, or network capacity constraints), and mesh networks, which allow for the creation of local "off the grid" networks to which people can connect with basic devices. While these types of solutions are less costly than developing extensive infrastructure in isolated communities, they nevertheless require a certain financial investment and technical expertise. Training involves a 
long-term investment that must develop as a partnership between CSOs, government, NGOs, public libraries and local universities. Capacity building is essential; having external website developers and trainers develop sites or one-shot training sessions will not have the long-term impact that can shift the technology balance of power toward Indigenous movements.

While authors disagree on the relative advantages of ICTs for resource-poor actors, the focus on Western cases (such as Occupy or that Spanish indignados) or on instances of social media mobilization among urban youth in developing societies ignores the particularities of the world's poorest communities. Indigenous peoples are unique not only because of their extreme socioeconomic marginalization, but because many of their demands distinguish them from other groups in society (claims over territory, demand for autonomy and promotion of a distinct identity) as do their traditional repertoire of tactics, which have generally involved large-scale mobilizations and are closely tied to place and identity. If social media has begun to take the place of organized protests and collective identity (the strengths of the indigenous movements in the 1980s-1990s) and if their access to ICTs is limited vis à vis other segments of society and state actors, what does this mean for their capacity to pursue their interests?

The inclusion of Indigenous experiences in the study of ICTs enhances our broader understanding of the impact of new forms of online civic engagement on marginalized actors. The research presented here suggests that while there are benefits and disadvantages, ICTs are tipping the balance of power away from Indigenous movements. Many of the characteristics that are said to characterize this new form of online activism not only run counter to Indigenous collectivism but diminish the very factors that made the Indigenous movements strong in the 1980s and 1990s: widely accepted collective goals over individual interests, shared Indigenous identity, strong ideological positions, powerful organizations and "one the ground" mobilization. 
In this context, the risk is that protest will become the domain of the middle classes in developing countries with high levels of inequality while Indigenous peoples be have more difficulty engaging in civic participation.

\section{References}

Albó, X. (2004). Ethnic Identity and Politics in the Central Andes. In J. Burt and P. Mauceri (Eds.), Politics in the Andes: Identity, Conflict, Reform. Pa.: University of Pittsburgh Press.

Biekart, K. \& Fowler, A. (2013). Transforming activisms 2010+: Exploring Ways and Waves. Development and Change, 44, 527-546.

Bengoa, J. (2000). La Emergencia indígena en América Latina. Santiago: Fondo de Cultura Económica.

Bennett, W.L. (2003). Communicating Global Activism: Strengths and Vulnerabilities of Networked Politics. Information, Communication \& Society, 6, 143-168.

Bennett, W.L. \& Segerberg, A. (2013). The Logic of Connective Action: Digital Media and the Personalization of Contentious Politics. Cambridge: Cambridge University Press

------. (2011). Digital Media and the Personalization of Collective Action: Social Technology and the Organization of Protests against the Global Economic Crisis. Information, Communication \& Society, 14, 770-799.

Bimber, B., Stohl, C., \& Flanagin, A. J. (2005). Reconceptualizing Collective Action in the Contemporary Media Environment. Communication Theory, 15, 365-88.

Bruns, Axel, Highfield, T \& Burgess, J. (2013). The Arab Spring and Social Media Audiences: English and Arabic Twitter Users and their Networks. American Behavioral Scientist, 57, 871898.

Brysk, A. (2000). From Tribal Village to Global Village: Indian rights and international relations in Latin America. Stanford, Calif.: Stanford University Press.

Carty, V. (2002). Technology and Counter-hegemonic Movements. Social Movement Studies, 1, 129-211.

Carty, V. \& Onyett, J. (2006). Protest, Cyberactivism and New Social Movements: The Reemergence of the Peace Movement Post 9/11. Social Movement Studies, 5, 229-249. 
Castells, M. (2009). Communication Power. Oxford/New York, Oxford University Press.

-----. (2009). The Rise of the Network Society, The Information Age: Economy, Society and Culture. $2^{\text {nd }}$ Edition. Cambridge, MA; Oxford, UK: Blackwell

-----. (2009b). The Power of Identity: The Information Age: Economy, Society and Culture. Vol II. $2^{\text {nd }}$ Edition. Cambridge, MA; Oxford, UK: Blackwell

-----. (2012). Networks of Outrage and Hope. Social Movements in the Internet Age. Cambridge, MA, Polity Press.

Chadwick, A. (2007). Digital Network Repositories and Organizational Hybridity. Political Communication, 24, 283-301.

Cleaver, J. (1998). The Zapatista Effect: The Internet and the Rise of an Alternative Political Fabric. Journal of International Affairs, 51, 621-64.

Garrido, M. \& Halavais, A. (2003). Mapping Networks of Support for the Zapatista Movement: Applying Social Networks Analysis to Study Contemporary Social Movements. In McCaughey \& Ayers (Eds.), Cyberactivism: Online Activism in Theory and Practice. London: Routledge.

Judem, E. (2012). In Ecuador, a Social Media Workaround. Columbia Journalism Review, March 26, 2012.

Langman, L. (2005). From Virtual Public Spheres to Global Justice: A Critical Theory of Internetworked Social Movements. Sociological Theory, 23, 42-74.

Lucero, J. (2008). Struggles of Voice: the Politics of Indigenous Representation in the Andes. Pittsburgh, Pa.: University of Pittsburgh Press.

Lupien, Pascal. (2011). The Incorporation of Indigenous Concepts of Plurinationality into the New Constitutions of Ecuador and Bolivia, Democratization. 18, 774-796.

-----. (2017). Technology, Indigenous Media and the New Power Dynamic in Bolivia. In Atrz, Burton Lee (Ed.) The Pink Tide: Media Access and Political Power in Latin America (Hoboken, NJ: Wiley-Blackwell).

Mijeski, K. \& Beck, S. (2011). Pachakutik and the Rise and Decline of the Ecuadorian Indigenous Movement. Athens: Ohio University Press.

Norris, P. (2001). Digital Divide? Civic Engagement, Information Poverty and the Internet Worldwide. Cambridge: Cambridge University Press.

Norris, P. and Inglehart, R. (2013). Chapter 9: Digital Divide. In Towse, R. (Ed.), Handbook on the Digital Creative Economy. Cheltenham, UK: Edward Elgar. 
Pickerill, J. (2003). Cyberprotest: Environmental Activism. New York: Manchester University Press.

Pilco, Sami. (2002). La Red Internet y los Pueblos Indígenas en América Latina: Experiencias y Perspectivas. Bergen, Norway: Institute for Media Studies, University of Bergen.

Postero, N. (2007). Now we are Citizens: Indigenous Politics in Postmulticultural Bolivia. Stanford, Calif.: Stanford University Press.

Postero, N. \& Zamosc, L. (2004). Struggle for Indigenous Rights in Latin America. Brighton [England]: Portland: Sussex Academic Press.

Salazar, J. (2015). Social Movements and Media Indígena in Latin America. In Pink, S. and Abram, S (Eds.), Media, Anthropology and Public Engagement. New York: Berghahn.

------. (2007). Indigenous Peoples and the Cultural Construction of Information and Communication Technology in Latin America. In Dyson, E. et al. Eds.), Information Technology and Indigenous People. Information Science Publishing.

Salter, L. (2003). Democracy, New Social Movements and the Internet. In McCaughey, M. \& Ayers, M.D. (Eds.), Cyberactivism: Online Activism in Theory and Practice. New York; London: Routledge.

Selverston-Scher, M. (2001). Ethnopolitics in Ecuador: Indigenous Rights and the Strengthening of Democracy. Coral Gables, Fla.: North-South Center Press at the University of Miami.

Stein, L. (2009). Social Movement Web Use in Theory and Practice: a Content Analysis of US Movement Websites. New Media and Society, 11, 749-71.

Trucco, L. (2013). The Digital Divide in the Latin American Context. In Ragnedda, M. and Muschert, G. (Eds.), The Digital Divide: The Internet and Social Inequality in International Perspective. New York; London: Routledge.

Rice, R. (2012). The New Politics of Protest: Indigenous Mobilization in Latin America's Neoliberal Era. Phoenix The University of Arizona Press.

Van Aelst, P. and Walgrave, S. (2003). New Media, New Movements: The Role of the Internet in Shaping the Anti-Globalization Movement. Information, Communication and Society. 6, 465493.

Van Cott, D.L. (2008). Radical democracy in the Andes. Cambridge, UK ; New York: Cambridge University Press.

-----. (1994). Indigenous Peoples and Democracy in Latin America. New York: St. Martin's Press. 
Vierecke, Linda. (2014). Why Community Radios Matter so Much to Indigenous People in Bolivia. Development and Cooperation, December 2014. Accessed August 25, 2016.

http://www.dandc.eu/en/article/why-community-radios-matter-so-much-Indigenous-peoplebolivia

Yashar, D. (2005). Contesting Citizenship in Latin America: the rise of Indigenous movements and the postliberal challenge. Cambridge; New York: Cambridge University Press.

\section{Notes}

${ }^{1}$ Interview, Ibarra (Imbabura), Sept. 14, 2016

${ }^{2}$ Interview, Cotacachi (Imbabura), July 27, 2016

${ }^{3}$ Interview, Ibarra (Imbabura), Sept. 14, 2016

${ }^{4}$ Interview, Cayambe (Pichincha), July 26, 2016

${ }^{5}$ Interview, Riobamba (Chimborazo), October 12, 2016

${ }^{6}$ Interview, Riobamba (Chimborazo), October 12, 2016

${ }^{7}$ Interview, Cotacachi (Imbabura), July 27, 2016

8 Interview, La Esperanza (Imbabura), July 27, 2016

${ }^{9}$ Interview, Cotacachi (Imbabura), July 27, 2016

${ }^{10}$ Interview, Quito (Pichincha), August 2, 2016

11 Interview, Riobamba (Chimborazo), October 13, 2016 